\title{
Integrated ecological education in the annual field courses to West Siberia
}

\author{
Pavel Barsukov* \\ Institute of Soil Science and Agrochemistry SB RAS, 630090 Novosibirsk, Russia
}

\begin{abstract}
Since 1995 soil field courses across bioclimatic zones in West Siberia were organized by a group of scientists from Siberia and Germany. These were soon transformed into annual (once a year) ecological field courses, which we believe successfully promote ecological education among students and young scientists from different countries. The courses were focused on virgin ecosystems undisturbed by anthropogenic influences, its individual components and more importantly multiple relationships between the components. The paper describes the main features of the field courses, the organization and changes in the content over the period of 2012-2019. This includes a short description of the field course route, interdisciplinary teaching approaches, the dynamics in number of participants. Special attention is paid to the evaluation of the courses by participants and results of the tests taken by student participants at the end of courses. Further proposals for improving the field courses are suggested.
\end{abstract}

The necessity of Environmental Education in the $21^{\text {st }}$ century is not in doubt in almost all countries. Although environmental education studies the functioning of the environment, it focuses primarily on human interactions with the environment and resulting environmental problems [1]. Recognizing the importance of Environmental Education, we believe that it should be based on ecology of natural ecosystems undisturbed by human activity. We consider this part of Environmental Education as Ecological Education, taking into account the classical definition of ecology as the relationship between living organisms and their abiotic and biotic environment or as "the study of the structure and function of nature" [2]. This paper discusses our experience in implementing environmental education by means of ecological field courses in West Siberia, the reasons for the success of these courses over a long period of time, and the results for their participants.

The first field courses were held in 1995 and initially focused only on soils. However, they were transformed fairly quickly (within 3 years) into annual (most commonly once a year) ecological courses. This is reasonable, because the Russian traditions in soil science were established on the concept of the founder of soil science, Prof. Vasily V. Dokuchaev. He defined soil as a special natural-historical body, formed in the interaction of soil formation factors: parent rock, climate, vegetation and animals, topography and geological age of a country [3]. On this basis, we shaped the concept and methodology of teaching in

* Corresponding author: barsukov@issa-siberia.ru 
our field courses. This was less an examination of individual components of ecosystems, but rather a consideration of the relationships between the major components of ecosystems: climate, parent (geological) material (geology), relief, biota (mostly plants), soil, and in some cases groundwater.

The southern part of West Siberia fits the objectives of our field courses perfectly, not only because it includes many "islands" of undisturbed nature, but also because of the great diversity of ecosystems/landscapes over a relatively short distance. We developed two routes that conveniently can be described as northern and southern. The northern route included the latitudinal bioclimatic zones/subzones within West Siberian Plain from the southern taiga to the typical steppe ecosystems through sub-taiga, northern and southern variants of forest steppe. Then it went across the Russian Altai Mountains, covering all possible altitudinal belts: lower, middle and upper parts of mountain forest belt, different variants of mountain steppe belt (dry steppe, desert steppe, edaphic semidesert), high mountain landscapes including mountain tundra, alpine meadows and cryophyte steppe/tundra-steppe. The southern route included the most southern part of West Siberian Plain (southern variant of forest steppe zone and steppe ecosystems), then it went across the Russian Altai Mountains (the same altitudinal belts as for the northern version), and then to the Mongolian Altai Mountains (including stony desert and shifting sand dunes with psammophytic plants). Total distance of both routes (round trip) was approx. $2900 \mathrm{~km}$ and the duration 24-26 days. Our field courses were organized as self-serving and self-sufficient expedition, which allowed us to be independent and flexible. Five vehicles, including two medium-size buses, a lorry, a minibus and a car usually accompanied the groups of participants for the whole field course period. We carried with us a supply of basic food for the entire trip and all the necessary shared equipment including facilities for cooking, tables and benches for 50 people, marquees over these tables, an electric generator, a multimedia projector for evening lectures and much more. Accommodation for participants was organized in tent camps typically near water bodies (lakes or rivers). A specialized Russian service team was responsible for managing the daily challenges.

The teaching was led by Russian scientists/lecturers (working in Siberian research institutes or universities) from different fields of knowledge, who accompanied the group of participants throughout the trip. We started our courses from acquaintance with participants, determination of their scientific background, focus contents, expectations, and specific wishes. We also gave common description of the courses, their route, everyday rules of outdoor life and brief safety instructions. Each participant was provided with a printed guidebook (up to 100 pages) with a detailed itinerary, a basic description of all the sites visited (briefly about climatic, topographic and geological features, and more about vegetation and soils), glossary of terms, and some information about interesting sites/phenomena that the participants might see during the passages from the bus window along the roads. Some other organizational features and logistics of the courses were described in our previous paper [4].

Educational program started from a review lecture on the biogeography of West Siberia and practical training devoted to field methods for studying and observing vegetation, soil, relief and geological material. This normally took two days and thereafter we travelled along the planned route making usually not more than two night stops at the same place. Along our route, we pre-selected 13 to $15 \mathrm{key} / \mathrm{main}$ sites. Two criteria guided our selection of the sites: (1) it should be an area undisturbed by human activity and (2) the site should be typical for the corresponding latitudinal zone/sub-zone or altitudinal belt/sub-belt. Based on these key sites we conducted the main teaching events in the form of field seminars. These seminars were led by 3 to 4 Russian lecturers who systematically alternated with each other, depending on their area of expertise. First, general information was provided on the climate, geomorphology, vegetation and soil cover of an area around a key site. 
Subsequently, in smaller groups, a deeper insight was given into the geological parent material, the plant communities, the soil morphology and the formation processes. Then came the most important part of a field seminar - to demonstrate the relationships and interdependence of the individual components of ecosystems. In addition, we often suggested that participants speculate on how a change in one component (e.g. climate) might change another component (e.g. vegetation) and how this would subsequently affect (directly and/or through feedbacks) a third component (e.g. soil). The absence of interference from human activities at each key site highlighted the natural relationships between ecosystem components, which greatly facilitated learning for participants. This uniform scheme was used for all field seminars at every key site, making it easier and more efficient for participants to absorb the information.

Below are some other particulars of examining a key site. The vegetation characterization included information on zonal and geomorphological positions, community type, and species richness. The ecological classification of plant communities and their associated ecosystems (syntaxonomic units such as class and order) was based on the Braun-Blanquet approach [5]. The guidebook contained full list of plant species subdivided on trees, shrubs, annual and biannual herbs, perennial herbs separately including grasses, legumes and forbs, and in some cases ferns. Every plant species in the lists was supplied by family name and name of ecological group with respect to water regime (hydrophytes, hygrophytes, mesophytes, xerophytes). In describing a soil profile, we paid less attention to details of soil morphology and more to soil formation processes and such factors that cause the formation of a particular profile as plant productivity and diversity, geological material, geomorphological and climatic characteristics, and groundwater. Soil names were given in accordance with International soil classification - World Reference Base [6].

After the main program of the field seminar, at each key site we offered participants to walk around in small groups to feel the features of the landscape with their feet, to touch something with their hands, to listen it and even to smell it. We considered such walks as an important part of ecological education and suggested them to participants wherever time and logistics allow. During these walks, participants often collected plants and minerals that interested them. At the request of the participants, Russian lecturers in the evenings identified this collected plant or mineralogical material and gave other consultations on specific questions that have arisen on this or the preceding days of the field course. In addition, during the field courses, Russian lecturers gave 5-7 presentations on interesting and actual topics with the use of a multimedia projector.

The main criterion for the success of our field courses is the very fact that they have been held over a long period of time. When we first offered the course in 1995, we didn't plan for it to be an annual course. Nonetheless, we were able to continuously recruit enough participants for full groups every year for 25 years (with the exception of one year in 1998) until 2019.The 2020 and 2021 field courses did not take place for reasons beyond our control due to the coronovirus pandemic.

Changes in the number of participants in the early years of the courses, the dynamics of courses evaluations by participants, and the educational effect of the courses from 1995 to 2011 were given in our previous paper [4]. In the present paper, we consider these issues for the period from 2012 to 2019 . We announced that the maximum desired number of participants is limited to 30-32 people. Over the period under review, the number of participants per a courses was consistently high, ranging from 30-33. The vast majority of participants (95\%) were from Germany and only 5\% from other countries (Austria, Switzerland, Hungary, Estonia, Czechia). This was because the main course organizers who recruited participants were from Germany, specifically professors from WeihenstephanTriesdorf University of Applied Sciences (HSWT). Therefore, the closest circle of dissemination and, accordingly, of recruited participants includes HSWT and the School of 
Life Sciences of the Technical University of Munich, located at Weihenstephan campus in Freising, Bavaria. A farther circle of dissemination includes other German universities. In addition to paying participants, we took at least two Russian students or young researchers each year on very favorable conditions.

This successful involvement of participants each year would not be possible without two factors: (1) the effective recruitment of students by the German organizers; and (2) the prominence and high reputation of our field courses, about which information was passed on from mouth to mouth, among the students and the staff of both above-mentioned and some other German universities. Previously, we also supported a courses' website, but as it was, it did not prove to be effective in finding participants for our courses.

One extra incentive for students to take part in the courses is that we offered the opportunity to pass a few tests and to get up to five European Credit points. Based on test results, we calculated grades and issued certificates that are fully accepted by German universities. This was coordinated with the German organizers of the field courses more than ten years ago. In general, students demonstrated a good grasp of the taught material in all subjects. The average grade for the eight years in geobotany was only slightly worse at 2.4 , and better in soil science at 1.7 , but both were at the "good" level (Table). The 8-year average coefficients of variation of the grades were $18 \%$ for geobotany $22 \%$ for regional climatology and $27-28 \%$ for soil science and geomorphology and geology.

Table. Evaluation of the field courses by participants and results of tests passed by students, average data for 2012-2019.

\begin{tabular}{|c|c|c|c|c|c|c|c|c|}
\hline \multicolumn{3}{|c|}{$\begin{array}{l}\text { Evaluation of person(s) } \\
\text { responsible for: }\end{array}$} & \multicolumn{3}{|c|}{$\begin{array}{l}\text { How sufficiently and clearly } \\
\text { was the information about ... } \\
\text { presented? }\end{array}$} & \multirow{2}{*}{\multicolumn{3}{|c|}{$\begin{array}{l}\text { Tests results (examination } \\
\text { grades) of student } \\
\text { participants by subject: }\end{array}$}} \\
\hline item & avg & $\mathrm{CV}$ & item & avg & $\mathrm{CV}$ & & & \\
\hline $\begin{array}{l}\text { organisational } \\
\text { matters in } \\
\text { Germany }\end{array}$ & 1.4 & 37 & $\begin{array}{l}\text { relationships } \\
\text { between } \\
\text { ecosystem } \\
\text { components }\end{array}$ & 1.7 & 42 & subject & avg & $\mathrm{CV}$ \\
\hline $\begin{array}{c}\text { management \& } \\
\text { implementation } \\
\text { of the courses in } \\
\text { Siberia }\end{array}$ & 1.3 & 38 & $\begin{array}{l}\text { introduction } \\
\text { and climate }\end{array}$ & 1.4 & 40 & $\begin{array}{c}\text { regional } \\
\text { climatology }\end{array}$ & 1.8 & 22 \\
\hline $\begin{array}{l}\text { teaching } \\
\text { geomorphology } \\
\text { and geology }\end{array}$ & 1.5 & 39 & $\begin{array}{l}\text { geology and } \\
\text { geomorpho- } \\
\text { logy }\end{array}$ & 1.5 & 39 & $\begin{array}{l}\text { geomorpho- } \\
\text { logy and } \\
\text { geology }\end{array}$ & 1.9 & 27 \\
\hline $\begin{array}{l}\text { teaching } \\
\text { geobotany }\end{array}$ & 1.4 & 38 & $\begin{array}{c}\text { flora and } \\
\text { vegetation }\end{array}$ & 1.5 & 40 & geobotany & 2.4 & 18 \\
\hline $\begin{array}{l}\text { teaching soil } \\
\text { science }\end{array}$ & 1.4 & 30 & soil & 1.3 & 34 & soil science & 1.7 & 28 \\
\hline
\end{tabular}

Notes. Based on German grading system ranging from 1.0 (excellent) to 5.0 (unsatisfactory); avg average grade, $\mathrm{CV}$ - variation coefficient of grades, $\%$.

An important way to measure the success of our courses and obtain the feedback was to conduct an anonymous survey of participants. We developed a 10-point questionnaire which included items on the organization and running of the courses, logistics and living conditions (meals, accommodation), shortcomings and suggestions for improving the courses. The completion of this questionnaire was on a voluntary basis. Nevertheless, in each group at least $90 \%$ of the participants filled in the questionnaire and did so very objectively and critically. Most important for us were the participants' evaluations of the scientific, educational, and organizational aspects of the field trip. We were pleased to note that all of these aspects are rated as "excellent" or very close to "excellent" (see Table). The average grades for 2012-2019 were: 1.4 for organizing courses by German organizers (CV 
$=37 \%), 1.3$ for conducting the tour by Siberian organizers and managers $(\mathrm{CV}=38 \%)$. The evaluation of individual lecturers in different subjects was also high: they received grades of 1.4-1.5 ( $\mathrm{CV}=30-39 \%)$, although some subjects were taught by different lecturers in various years. In addition, the questionnaire included another question: "Have you got enough information about the following items and was the content of subjects clearly described?". Although there was a wide variation in the answers to this question (CVs were $39-42 \%$ for four of the five topics), in general the participants rated the completeness and clarity of the information on the all topics as "excellent" and "good".

Given the success of the field courses for Ecological Education, we consider it would be appropriate to continue them in the future once restrictions related to the coronovirus pandemic are lifted. Despite the high appreciation of our field courses by their participants, we believe there is further room for improvement in the content of the courses. Of course, the focus of the courses should remain on the various virgin ecosystems and the mutual relationships between its components. But it will also be beneficial to demonstrate how natural ecosystems can be used as reference objects for changed or artificial environments. In addition, we consider it would be useful to strengthen the interdisciplinary approach to teaching as well as the advantages of outdoor instruction. This allows, unlike textbooks, to clearly illustrate, for example, the absence of sharp boundaries in nature, smooth transitions between climatic characteristics, plant communities, soil types.

With regard to organizational issues, we consider the following to be appropriate for the further development of the Siberian field courses.

(i) To increase the involvement of students and young academics from countries other than Germany and to encourage them to seek funding for participation in our field courses.

(ii) To invite a few experienced foreign scientists with a somewhat different school/scientific background from Siberian scientists to participate in each course. This should greatly enrich discussions on various topics.

(iii) Actively engage more foreign scientists and students to carry out research projects on the territory of Siberia together with Siberian scientists.

Acknowledgements. I wish to acknowledge the German organizers of the field courses for the last decade: Prof Christian Siewert, Prof Frieder Luz and Prof Christian Huber. I would also like to express my sincere appreciation to all the Siberian scientists who have supported the development of our field course over the years: Prof N. Lashchinsky, Dr. B. Smolentsev, Ms E. Smolentseva, Mr O. Saprykin, Dr S. Gizhitskaya, Dr S. Platonova, Dr O. Pisarenko, Dr N. Makunina, Dr I. Lyubechansky, Dr M. Dirks, Prof A. Babenko, Dr S. Loiko. The study was carried out partly in accordance with the state assignment of the Institute of Soil Science and Agrochemistry of the SB RAS.

\section{References}

1. H. Tanaka, J. Indian Chem. Soc. 77, 531 (2000)

2. E. P. Odum, Fundamentals of Ecology (1971)

3. V. V. Dokuchaev, Russian chernozem (1883)

4. C. Siewert, P. Barsukov, S. Demyan, A. Babenko, N. Lashchinsky, E. Smolentseva, Environ. Educ. Res. 20, 858, (2014)

5. V. Westhoff, E. Maarel, Classification of plant communities (The Hague, 1978)

6. IUSS Working Group, World Reference Base for Soil Resources, 106 (2015) 